\section{Level pegging for UK research funds \\ - Inflation likely to erode increases - Research councils to absorb overhead costs}

\section{London}

LAST week's announcement of the 199192 science budget for the UK Department of Education and Science (DES) caused general disappointment in the British scientific community. Total research spending is likely to shrink in real terms, unless inflation is very rapidly brought under control. But spending on higher education in 1991-92 will be higher than expected, which may help alleviate the current university funding crisis.

The DES science budget is the largest single slice of UK government support for civil science. Early next year it will be divided up between the five research councils and the grant-in-aid of the Royal Society. The $£ 928$ million announced by the new Secretary of State for Education and Science, Kenneth Clarke (who replaced John MacGregor in the latest reshuffle of cabinet ministers), compares with $£ 897$ million being spent in 1990 - 91 , but in the tradition of UK government statistics, a direct comparison between the two figures is difficult. The $£ 928$ million includes money received from European Communities' research programmes, and is further complicated by changes in the payment of research students' tuition fees, and a transfer of money from elsewhere in the DES budget to support academic supercomputing.

Professor Denis Noble, president of the academic pressure group Save British Science, says that however the figures are massaged, they represent "at least a freeze and possibly worse".

According to Clarke, the value of the science budget in 1991-92 will be preserved in real terms, but this assumes an inflation rate of six per cent over the coming year - an optimistic forecast, given that the current rate exceeds ten per cent.

Clarke also announced that, from 1992-93, the research councils must pay for all the costs of research they support in higher education institutions, apart from academic salaries and the cost of building maintenance, heating and lighting. At present, a large proportion of the overhead costs of research council projects in the universities are met from the grants awarded to universities by the Universities Funding Council (UFC). The change was originally planned for 1991-92 (see Nature 343, 199; 18 January 1990), but has been delayed by a year at the suggestion of the Advisory Board for the Research Councils, to allow a "smooth and effective transfer" of funds from the UFC to the
DES science budget. To cover research project overheads, a total of $£ 50$ million will be added to the science budget for $1992-93$, and $£ 100$ million for the following year.

The Committee of Directors of Polytechnics has broadly welcomed this

\section{IMAGE UNAVAILABLE FOR COPYRIGHT REASONS}

Kenneth Clarke - looking optimistic change, which should allow polytechnics to compete more effectively with the universities for research council grants.

\section{Cape Town}

Sourn Africa's 21 universities are to have their state subsidies cut by 3 per cent in real terms next year, at a time when inflation is running at 15 per cent per year. Five universities (Rhodes, the Rand Afrikaans University, and the universities of South Africa, Pretoria and the Witwatersrand) have already responded by announcing fee increases of between 20 and 25 per cent, and the others are expected to follow suit shortly.

According to an agreement between the government and the Committee of University Principals, the government pays for 80 per cent of the cost of each student's place at a university. But in practice, increasing student numbers have led to this portion declining since 1986. Although next year's 3 per cent decrease in state support is in line with government cuts in other budget areas, it is the first time that universities have been hit with a decrease; this year all universities received an increase of $6 \%$ on last year's subsidies.

Nevertheless, this is the third year running that subsidies to the universities will not be calculated, as they have been in the past, according to the enrolment figures two years before the funding year (see Nature 340, 420; 1989). This means that subsidy entitlements have been frozen on
But Professor Terrence Burlin, rector of the Polytechnic of Central London, says he is "extremely disappointed" that the change has been delayed for a year, for no obvious reason. And the transfer of funds still leaves a massive imbalance in research support between the two sectors: polytechnics receive only about $£ 30$ million a year for research from the Polytechnics and Colleges Funding Council, compared with over $£ 700$ million research support entering the universities from the UFC.

Funding for higher education is set to increase by some ten per cent in 1991-92. This will finance about three-quarters of the planned five per cent increase in university student numbers, at current teaching costs. Although universities will still have to look for economies (or consider charging fees to students) if they are to expand as planned, the UFC's budget for 1991-92 is greater than many vice-chancellors had expected. But as with the DES science budget, the increase in real terms will depend on the inflation rate over the coming year. Academic pay rises may also erode the increased budget. Clarke told the House of Commons last week that a proportion of the universities' grants may be held back in the absence of a "satisfactory" pay settlement.

Peter Aldhous

\title{
Cuts cause fees to rise
}

the basis of 1986 enrolment figures, which has had serious consequences for universities that have grown most since then - the universities of Zululand, the Western Cape, Fort Hare and South Africa are currently operating on subsidies which constitute less than 70 per cent of their entitlement, and will be in an even worse position next year.

Higher fees make university education less accessible to less affluent sectors of the population, and will do nothing to narrow the difference in participation rates between white and black South Africans, which now stand at 30 and 3 per thousand of population respectively. Students receive no maintenance grants from the South African state, so these costs, as well as fees, have to be met by themselves or their parents. Some receive bursaries (with service contracts) from the government or the private sector, and the balance made up by loans from banks, which require either parents or the university to stand surety for them. University of Cape Town vice-chancellor Stuart Saunders responded to the cuts by calling for the establishment of a national state bursary fund to help university students, especially from underprivileged communities.

Michael Cherry 